\title{
PRÁTICAS DE LEITURA EM DIFERENTES ESPAÇOS ESCOLARES
}

\author{
Andressa Garcia Castilho ${ }^{1}$ \\ Adriana Pastorello Buim Arena ${ }^{2}$
}

Resumo: 0 artigo apresenta o recorte de uma pesquisa de cunho qualitativo que teve como parâmetros metodológicos os pressupostos do estudo de caso do tipo etnográfico. A investigação foi realizada em uma Escola Municipal da cidade de Uberlândia-MG. O objetivo foi o de investigar se a concepção de leitura dos professores em uma classe de $2^{\circ}$ ano do ensino fundamental influenciava a forma como eles utilizavam os espaços da escola e seus respectivos recursos para a formação de alunos-leitores. A coleta de dados e materiais se efetivou por meio de observações e de entrevistas realizadas com uma professora responsável pela classe, duas professoras da disciplina Literatura e Música, dois laboratoristas e uma professora que atuava na biblioteca escolar. Os ambientes escolhidos foram a sala de aula, 0 laboratório de informática, a biblioteca e um quiosque. A análise dos dados está baseada nas concepções sobre leitura apresentadas por Kleiman, Smith, Foucambert e Silva. Ao final da pesquisa foi possível perceber que a ação docente é sempre guiada por uma concepção teórica, embora as professoras não tenham consciência disso.

Palavras-chave: Organização do espaço escolar. Desenvolvimento da leitura. Concepção.

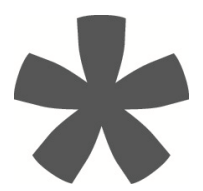

1 Mestre em Educação. Aluna do Programa de Pós-Graduação em Educação da Universidade Federal de Uberlândia. E-mail: andressa_gcastilho@yahoo.com.br

2 Mestre em Educação e Doutora em Educação pela Universidade Estadual Paulista Júlio de Mesquita Filho. Bolsa de doutorado-sanduíche financiada pela CAPES na Faculdade de Psicologia e Ciência da Educação da Universidade de Lisboa. E-mail: dricapastorello@gmail.com 


\section{READING PRACTICES IN DIFFERENT SCHOOL ENVIRONMENTS}

Abstract: This paper presents the fragment of a qualitative research that had as methodological parameters the ethnographic case study approach. The research was conducted in a municipal school in Uberlândia-MG. The objective was to investigate whether the teacher's conception of reading in a 2nd year class of elementary school influenced the way they used the school environments and its resources for the training of students-readers. Data collection and material was accomplished through observations and interviews with a teacher responsible for the class, two teachers of the course Literature and Music, two laboratory technicians and a teacher who worked in the school library. Classroom, computer lab, library and a kiosk were the environments chosen. Data analysis is based on the concepts on reading presented by Kleiman, Smith, Foucambert and Silva. At the end of the survey we noticed that the teaching action is always guided by a theoretical concept, but the teachers are not aware of it.

Keywords: School environment organization. Reading development. Conception.

\section{PRÁCTICAS DE LECTURA EN DISTINTOS ESPACIOS ESCOLARES}

Resumen: Este artículo presenta un recorte a una investigación cualitativa que tuvo como parámetros metodológicos los supuestos del estudio de caso de tipo etnográfico. La investigación se realizó en una escuela municipal de la ciudad de Uberlândia-MG. El objetivo fue investigar si el concepto de lectura de los maestros en una segunda clase anual de la escuela primaria influenciaba en la forma en que se utilizan los espacios de la escuela y de sus recursos para la formación de los estudiantes-lectores. La recolección de datos se logró a través de observaciones y entrevistas hechas por una profesora responsable por la clase, dos maestros de la disciplina Literatura y Música, dos técnicos de laboratorio y un maestro que trabajaba en la biblioteca de la escuela. Los ambientes fueron elegidos fueron el aula, el laboratorio de computación, la biblioteca y un quiosco. El análisis de datos se basa en la lectura sobre los conceptos presentados por Kleiman, Smith, Foucambert y Silva. Al final de la encuesta se reveló que la acción docente siempre se guía por un concepto teórico, pero los profesores no son conscientes de ello.

Palabras clave: Organización del espacio escolar. Desarrollo de la lectura. Concepción. 


\title{
Introdução
}

O desejo de investigar o espaço concedido à leitura dentro da escola se originou de indagações cotidianas provocadas pela percepção de pequenos gestos e situações presentes no cotidiano escolar. Os profissionais formadores de leitores, sujeitos desta pesquisa, tinham acesso a livros e a materiais, mas não reconheciam a necessidade de tornar o ato de ler um ato próprio de sua cultura e de seu papel de formador realizado em circunstâncias diversas. Segundo Silva (1998, p. 2), “[...] nesse ciclo de criação e recriação do conhecimento, próprio da escola, a leitura ocupa, sem dúvida alguma, um lugar de grande destaque". Também é esta a opinião assumida neste artigo e constatada durante o processo de permanência da pesquisadora na escola para realização de estágio acadêmico.

$\mathrm{Na}$ instituição em que foram realizadas as observações, notava-se que a leitura estava associada à execução de tarefas escolares, consequentemente os alunos a realizavam por obrigação e com desânimo; os exercícios de leitura propostos pelos professores não os estimulavam a ler, ao contrário, tornavamse os momentos mais enfadonhos do período escolar. Segundo Smith (1989, p. 212-213):

\begin{abstract}
A leitura pode tornar-se uma atividade desejada ou indesejada. As pessoas podem tornar-se leitores inveterados. Também podem tornar-se não-leitores inveterados, mesmo quando são capazes de ler. Uma tragédia da educação contemporânea não é tanto de muitos estudantes abandonarem a escola incapazes de ler e de escrever, mas que outros se formam com uma antipatia pela leitura e escrita, apesar das habilidades que possuem. Nada, acerca da leitura e de instrução, é inconsequente.
\end{abstract}

Os dados que aqui serão expostos e discutidos fazem parte de uma pesquisa maior que se propunha a investigar a maneira como os professores do $2^{\circ}$ e do $5^{\circ}$ ano do ensino fundamental de uma escola pública da cidade de Uberlândia, Minas Gerais, utilizavam os espaços da escola para a formação de leitores. Entretanto, para este artigo serão apenas apresentados os dados coletados de observações e de entrevistas realizadas com os profissionais do $2^{\circ}$ ano do ensino fundamental. A sala de aula, a biblioteca, o laboratório de informática e um quiosque foram considerados espaços de múltiplas 
possibilidades para a realização de atividades em torno da leitura, por isso serão apresentados nos itens subsequentes deste texto. Durante a pesquisa, investigou-se como tais ambientes se organizavam na perspectiva de formar o aluno leitor; quais práticas eram desenvolvidas pelos professores para explorar esses locais; o que pensavam os professores sobre o termo leitura e quais eram os livros utilizados nas atividades propostas. No decorrer deste texto serão apresentadas as respostas a estas indagações.

Tomou-se como ponto de partida o fato de a escola pública ser uma instituição que deve interferir diretamente na formação leitora do indivíduo. A maioria dos membros de famílias de baixo poder econômico, sem acesso a livros e a modelos de leitores eficientes em seu meio familiar, tem como referência inicial a escola e seus profissionais. Vale ressaltar que,

[...] embora a leitura não seja posse da escola, é papel da escola garantir a democratização da leitura e da produção escrita. A leitura não pode ser reduzida a práticas extra ou intra-escolares, mas precisa ser encarada como importante no interior de um amplo projeto de política cultural [...] (KRAMER, 1999, p. 135).

Essa perspectiva de ensino como um engajamento sociopolítico contribuiu como aporte teórico do processo investigativo ao trazer luz à reflexão sobre a atitude do docente e seus objetivos ao propor práticas de leitura em diferentes espaços escolares. De acordo com estudos de Vigotsky (2009) e Leontiev (1978), os sujeitos aprendem quando estão envolvidos em uma série de ações conscientes, bem planejadas e elaboradas para atingir o seu centro de interesse e, consequentemente, desencadear o processo de aprendizagem. No entanto, a forma como cada professor organiza seu trabalho de ensino está subordinada a sua concepção metodológica, a sua visão de ciência e de mundo, mesmo que ele não tenha disso clara consciência.

Eleger uma metodologia de ensino da leitura que priorize a relação grafofônica em detrimento da compreensão coloca obstáculos para que o aluno se torne um verdadeiro leitor, porque a escrita é também alfabética, mas essencialmente ideográfica (BAJARD, 2014). 
Vários são os exemplos de professores que utilizam a leitura associada a uma tarefa ou distribuição de notas. Pesquisas realizadas por Cereja e Magalhães (2005) revelam que esta função meramente tarefeira (didática) do ensino da leitura não oferece subsídios para cultivar leitores; os alunos apenas cumprem deveres. Nesse aspecto, a leitura estaria apenas no âmbito das obrigações e dificilmente se tornaria parte do dia a dia, utilizada em decorrência de situações específicas e de uso social. Para Smith (1989, p. 198),

A leitura nunca é uma atividade abstrata, sem finalidades, embora seja frequentemente estudada deste modo por pesquisadores e teóricos e, infelizmente, ainda seja ensinada deste modo para muitos aprendizes. Os leitores sempre lêem algo, lêem com uma finalidade; a leitura e sua rememorização sempre envolvem emoções, bem como conhecimento e experiência.

A escola é constituída por grupos diversos, múltiplos e heterogêneos que sofrem influências e interferências da sociedade. Por considerar tal diversidade, esta pesquisa se baseou nos pressupostos do estudo de caso do tipo etnográfico, porque visa a analisar e a refletir sobre a particularidade e, ao mesmo tempo, a complexidade de uma situação singular no contexto escolar (ANDRÉ, 1995).

Nesta perspectiva metodológica, após um semestre de observações em 2012, a coleta de dados teve a duração de três meses - março, abril e maio -, durante o primeiro semestre de 2013. Além dos registros realizados durante a observação, a entrevista também foi utilizada como instrumento de coleta. Foram entrevistadas a professora regente, polivalente, responsável pela classe; duas professoras de Literatura e Música, disciplina que compõe o currículo escolar; dois laboratoristas; e uma professora que atua na biblioteca escolar. No decorrer do texto, quando for necessário fazer referência a todos os entrevistados de uma só vez, será usada a expressão profissionais da educação.

Além da introdução, o artigo está organizado em cinco partes, que correspondem aos ambientes escolares observados e explorados para a formação do leitor. 
A Sala de Aula

O currículo escolar oferece Literatura e Música semanalmente como parte integrante de um quadro de disciplinas denominadas por aulas especializadas. Com elas os alunos têm contato com outras professoras, além daquela titular da classe, polivalente e responsável por ensinar todas as outras matérias que compõem o currículo.

As responsáveis por essa disciplina eram as professoras aqui denominadas pelas iniciais de seus nomes, G. e M. Para a professora G., o objetivo dessa disciplina era formar alunos "mais críticos, mais autônomos, mais espontâneos, para perder aquela vergonha que eles têm; e os que são mais inibidos eu peço para eles recontarem a história, e o tímido, às vezes quando você olha, ele está cantando as músicas baixinho" (Entrevista 08/04/2013). Quanto à professora M., ela entendia, para além do objetivo de ensino, que "a aprendizagem não é somente o conhecimento, mas trazer um pouquinho de valor hoje, a família está desestruturada, o pai e a mãe não estão tendo tempo de ensinar nem as coisas básicas; para escola o principal é o conteúdo, mas eu faço além do conteúdo" (Entrevista 09/04/2013). Nas aulas ministradas pela professora G., o alvo da formação era proporcionar aos alunos sua autonomia e de serem capazes de compreender melhor as relações sociais tendo a literatura e a música como matéria-prima para desencadear as reflexões e as práticas.

A leitura em geral e a leitura de literatura são fundamentais para que os sujeitos aprendam, pensem, transformem seu mundo interno, subjetivo, mas também o mundo social, histórico e cultural; é pela linguagem escrita que o ser humano pode experimentar, vivenciar emoções, sensações, pensamentos de nível superior, que talvez nunca venham a ter oportunidade em sua vida cotidiana, ou, talvez, que essas atividades psíquicas possam demorar muito a chegar, ou até a vir em doses muito pequenas. Segundo Silva (1998, p. 89), é grande o potencial que a literatura pode despertar no homem:

Curiosidade. Imaginação. Criatividade. Fantasia. Sentimento. Invenção. Sensibilidade. A literatura, enquanto expressão da vida, tem a capacidade de redimensionar as percepções que o sujeito possui de suas experiências com o mundo. Por isso, mesmo, a leitura de literatura, pela natureza e pela sua força estética, colabora significativamente para a formação de pensar e de encarar a vida. 
Os alunos, ao terminarem suas tarefas ou enquanto aguardavam que os próximos colegas as finalizassem, podiam retirar livros do "cantinho da leitura" e os ler em suas próprias mesas. Eram oferecidos para as crianças livros com textos curtos e também gibis, bem disputados, mas a leitura de livros de literatura não era prioritária.

A professora regente do $2^{\circ}$ ano, entretanto, propunha a seus alunos a leitura de diferentes gêneros textuais. Durante o período de observação, foi possível acompanhar o trabalho feito com cartas, panfletos, convites, contos e fábulas. A aula mantinha sempre o mesmo ritual: expositiva no início; em seguida, eram distribuídas folhas xerocadas para que os alunos iniciassem as atividades propostas após a explicação. Geralmente, as perguntas eram relacionadas com o que a professora havia explicado enquanto falava sobre o assunto. Na entrevista - quando questionada sobre o conceito de leitura, como se forma um leitor e quais seriam os recursos necessários para a formação de leitores -, ela relata:

A criança ser letrada, quando você sabe ler, não é só decodificar o texto, você saber ler é interpretar, é um letramento e interpretação. Às vezes, você pode saber ler, mas você é um analfabeto funcional igual aos meninos da sala do quinto ano. Têm alguns que leem bem. Às vezes, eles estão lendo o texto, mas não entendem o que o texto quer falar, por falta de trabalhar interpretação com eles. Eu tento trabalhar, mas a gente não faz milagre dentro de um ano. $\dot{E}$ muita concepção de professor, eu vejo assim; estou na educação há 25 anos, eu quero encerrar como aquele professor que trabalhou e não como aquele que empurrou; não quero esse aspecto negativo. Quero propiciar condições para eles lerem, pra eles lerem e produzirem, trabalhar com gêneros que são propostos e estimular os meninos a trabalhar, igual levamos pra informática, trazemos vídeos, mas olhando a linguagem, tem muito material para trabalhar. Estava vendo vídeos sobre a visão do negro em relação à escravidão. Eu ensino que a gente tem que ter duas visões, a visão dos negros e dos brancos, e, em cima dessas, você tira a sua opinião. É muito difícil, não é todo mundo que trabalha. 0 livro Porta aberta tem as melhores visões, tem gráficos tabelas, acho bom (Professora regente- entrevista 24 mar. 2013).

As tarefas de leitura se restringiam à leitura de textos do livro didático e às perguntas que se encontravam na sequência. A professora acompanhava a ação de ler e, ao sinal de qualquer pronúncia errada da palavra ou equívoco 
de pontuação, ela parava e corrigia o aluno para que lesse, ou melhor, pronunciasse corretamente. Esse procedimento acontecia com a leitura de qualquer texto, até mesmo com aqueles com que as crianças nunca tiveram contato. Em relação à tentativa de corrigir os textos proferidos, Smith (1989, p. 16) diz:

Ler é menos uma questão de extrair sons de letras impressas do que dar significado a estas letras. Os sons, que supostamente devem revelar o significado de seqüências de letras, não podem, na verdade, ser produzidos, a menos que um significado provável possa ser determinado com antecedência. É fato universal que o esforço para ler através da decodificação é amplamente fútil e desnecessário.

Dentre outros motivos, o autor destaca que o esforço de pronunciar palavra por palavra pode afetar diretamente a compreensão global do texto, princípio básico da leitura. Um bom exemplo para explicar tal episódio é que o movimento dos olhos não é linear, seus movimentos são rápidos e sacádicos, portanto não identificam cada palavra na sua integridade gráfica. Segundo Smith (1989), conseguimos em média ler seis palavras, em apenas um lance de olhar. Isso se deve ao que ele explica sobre a memória e como ela atua na leitura. Durante o processo de ler, a memória - denominada de curto prazo - é esvaziada constantemente, somente o que é significativo fica retido na memória de longo prazo.

Considerando essas afirmações do autor, o fato de focar a atenção letra por letra pode atrapalhar a compreensão, tendo em vista o controle que o leitor precisa ter para voltar o olhos sempre para um ponto específico do texto, impedindo, assim, seus movimentos naturais de saltos rápidos pela página. A observação revelou que a professora esperava, por parte das crianças, já no contato inicial com o texto, que proferissem-no com a mesma competência de um leitor já experiente. Provavelmente, ler em voz alta para toda turma não garantiria a compreensão do texto para o próprio leitor. Embora a professora tenha consciência de que ler é sinônimo de compreensão, sua proposta metodológica não valoriza o significado da palavra lida, mas a sua pronúncia. 
Nas outras disciplinas, a condução das atividades era a mesma na abordagem da leitura. A professora utilizava livros didáticos em sala e pedia a leitura dos textos; explicava o conteúdo e solicitava que respondessem as perguntas. Geralmente, as questões de compreensão eram facilmente respondidas, porque exigiam do aluno apenas sua localização. Em relação a essa prática, Silva (1998, p. 3-4) explicita:

O caráter estritamente livresco do ensino e as formas autoritárias através das quais os livros são apresentados em sala de aula tendem a contribuir para a socialização dos estudantes, gerando a falsa crença de que tudo o que está escrito ou impresso é necessariamente verdadeiro. Decorre daí a obediência cega aos referenciais colocados nos livros e a reprodução mecânica de ideias captadas pela leitura. Nesse caso, os processos de memorização de conteúdos pré-fixados que são determinados pelos textos e reforçados pelos professores - tomam o lugar do conhecimento e do questionamento, da discussão e crítica das ideias vinculadas, impedindo que o aluno leitor se torne sujeito do trabalho que executa.

O autor ressalta a importância de criar outras condições para explorar o texto, além daquelas apresentadas pelo livro didático, de maneira que o aluno possa estabelecer relações e participar ativamente de seu próprio processo de ensino. Outro ponto que merece atenção especial nesta reflexão é a importância do papel da visão crítica no percurso da aprendizagem. 0 espírito crítico é desenvolvido durante o processo de formação e só pode ser conquistado se o professor ajudar o leitor iniciante a enxergar diferentes pontos de vista para além daquele apresentado pelo livro didático.

Durante a pesquisa, foi possível analisar o material de leitura adotado pela professora regente, a cartilha Alegria do Saber. O referido manual de ensino não contribui com o desenvolvimento da criticidade, porque seus textos não promovem o debate. Eles são basicamente constituídos por frases curtas que não fazem sentido e significado em relação à vida social e cultural dos alunos.

Às vezes, esse mesmo material utilizado cotidianamente com os alunos do $2^{\circ}$ ano era utilizado com os do $5^{\circ}$ ano em aulas de reforço. A professora reconhecia que os textos eram ruins, mas afirmava que achava a melhor maneira de conduzir os trabalhos em sala, porque tinha alunos que não 
conheciam sequer uma palavra, e, com a cartilha, ela conseguiria igualar o nível de aprendizagem deles. Com a intensificação do trabalho com as famílias silábicas, aqueles que já sabiam ler e escrever, segundo seu ponto de vista, poderiam sedimentar o conhecimento e esperar aqueles que ainda não apresentavam o mesmo desempenho.

A cartilha era trabalhada desde do início do ano, letra a letra, sílaba a sílaba. A intenção da professora era que todos estivessem lendo ao final do ano letivo, mas sua maior preocupação estava voltada para o reconhecimentos dos grafemas e dos fonemas. Segundo ela, se os alunos aprendessem bem a relação grafofônica, ao visualizar qualquer palavra conseguiriam pronunciar seu som em um curto período de tempo. Depois de aprenderem a extrair o sons das palavras, ela poderia começar a utilizar textos melhores, mas ainda retirados de livros didáticos.

Existe por trás desse depoimento a crença de que é preciso primeiro conhecer os sons das letras para depois thes atribuir o sentido. 0 conhecimento é complexo e se faz na complexidade, já que são muitas as informações necessárias para atingir a compreensão de um texto, muito mais que o simples conhecimento das letras do alfabeto e seus sons correspondentes. Para Kleiman (1989, p. 18-19),

[...] a leitura é considerada um processo interativo, no sentido de que os diversos conhecimentos do leitor interagem em todo o momento com o que vem da página para chegar à compreensão. A leitura não é apenas a análise das unidades que são percebidas para, a partir daí, chegar a uma síntese. Também a partir da síntese ela procede a análise para verificar suas hipóteses, num processo em que, repetimos, tanto os dados da página como o conhecimento do leitor interagem em fontes de dados necessários a compreensão.

A leitura não é algo reduzido ao simples reconhecimento das letras. Acreditar nisso seria reduzir o seu papel. Ler não é sonorizar palavras, localizar informações, mas é por meio das marcas gráficas que os leitores criam possibilidades de conexões com o mundo externo e interno, e essas conexões permitem ao leitor fazer inferências sobre diversos assuntos, encontrar respostas, mas também elaborar novas perguntas e ao mesmo 
tempo se constituir um sujeito mais crítico e autônomo. Segundo Foucambert (1994, p. 5),

Ler significa ser questionado pelo mundo e por si mesmo, significa que certas respostas podem ser encontradas na escrita, significa poder ter acesso a essa escrita, significa construir uma resposta que integra parte de novas informações ao que já se é.

Neste item, foi possível apresentar as preocupações da docente com relação ao ensino da leitura. Seu objetivo profissional era ensinar as crianças a ler e compreender textos, mas, ao contrário, suas práticas e escolhas faziam com que os alunos aprendessem a oralizar, pronunciar textos e não propriamente a compreendê-los. "A escola ensina o aluno a se tornar um recitador em vez de se tornar um leitor, confusão que a própria história do ensino terminou por elaborar" (ARENA, 2010, p. 6).

\section{O Laboratório de Informática}

O laboratório de informática contava com dois profissionais - W. e P. -, que, em entrevista, afirmaram não ter nenhuma responsabilidade com o ensino da leitura e da escrita. Eles ressaltaram que realizavam tarefas além daquelas previstas, como preparar atividades para serem realizadas durante a aula de informática, por exemplo. Segundo W., "a aula é do professor, ele tem que planejar. O que eu faço é auxiliar ele e mostrar quais são as opções, implementar ideias, aqui o que acontece, aqui a gente troca muito, eu dou muita ideia, mas porque o ambiente dessa escola favorece" (Entrevista 26 mar. 2013). Ele tentava ajudar, mas reclamava que alguns professores não planejavam a aula, não the avisavam sobre o conteúdo que estava sendo ensinado em sala e, por este motivo, improvisava atividades e jogos de acordo com a idade da turma. Ressaltou também que, devido a sua formação em Matemática, não tinha conhecimento didático para trabalhar com o ensino da leitura e da escrita com crianças. Sobre este fato, P. complementou: “o professor tem que me passar o que ele quer, o meu trabalho é auxiliar, a parte pedagógica é com ele, quando o aluno não sabe usar a ferramenta, o computador, aí eu tenho que intervir, essa é minha função, mas a gente faz mais que isso" (Entrevista 27 mar. 2013). 
Aliado ao analfabetismo que ainda existe em grande escala em nosso país, nos últimos tempos ainda enfrentamos o processo de marginalização do acesso aos meios digitais, principalmente aqueles ligados ao uso da internet e à rede de computadores. Isso pode justificar a existência de muitos programas de inclusão digital, seja para o uso escolar, seja para a inserção de pessoas no mercado de trabalho. $O$ fato é que a cada dia o uso do computador passa a ser exigido e em diversas situações.

$\mathrm{Na}$ tentativa de inserir os alunos na era da informática, a escola criou esse espaço. O laboratório de informática e sua ligação com o ensino se justificam por diferentes vias, quer seja a mercadológica, atrelada a uma proposta neoliberal de política econômica do Brasil, quer seja pelo nobre ato de oferecer aos estudantes condições de apropriação de um instrumento de leitura e de escrita criado pela humanidade.

Dwyer et al. (2007) destaca que, na realidade brasileira, desde os tempos de industrialização, iniciou-se um investimento em informática para criar jovens com futuros promissores e capacidade de competir no mercado. Segundo o autor, inicialmente houve um investimento em criação de laboratórios em escolas particulares que, ao longo de seu uso, comprovou sua contribuição para com o processo de ensino; como consequência, a informática passou a ser vista como essencial para o sucesso dos alunos. Entretanto, a popularização desses saberes ocorreu por meio da LDB e de alguns programas, como o Programa Nacional de informática na Educação (PROINFO), que investiram na disseminação desta tecnologia na rede pública de ensino. Como tudo que é novo desperta mais curiosidade para o público usuário, muitos profissionais passaram a discutir a importância da tecnologia digital em detrimento de outros recursos. Para Silva (1998), nenhum material que ainda tem seu uso no cotidiano social deve ser descartado, pois é na escola, ou deveria ser, que o aluno tem a oportunidade de aprender a usar estes recursos disponíveis com criticidade.

Durante o período de investigação, todas as aulas ministradas no laboratório apresentavam o mesmo padrão de atividades. Nesse espaço, as turmas eram organizadas por sexo, uma menina sentava-se ao lado de um 
menino. O laboratorista deixava todos os computadores ligados com a atividade que deveria ser realizada pela criança na página de entrada.

As propostas didáticas desenvolvidas no laboratório foram especificamente relacionadas às disciplinas de Matemática e de Português. A prática de jogos para diversão era frequente. Ao final da atividade programada para a aula, e somente em uma única vez, os alunos usaram a internet para fazer pesquisa. Observou-se que o uso do computador não passava de uma mera transposição das atividades encontradas no material didático utilizado em sala de aula. A atividade era projetada na tela e não no papel. Os alunos se acomodavam em outro ambiente; saiam de cena os lápis e entravam os teclados, mas o objetivo era o mesmo da sala de aula: reforçar a memorização da ortografia de um determinado grupo silábico ensinado. $\mathrm{Na}$ imagem 1, a tela do computador apresenta uma atividade que reforça a memorização do dígrafo ch e a página da cartilha a da letra $Z$.
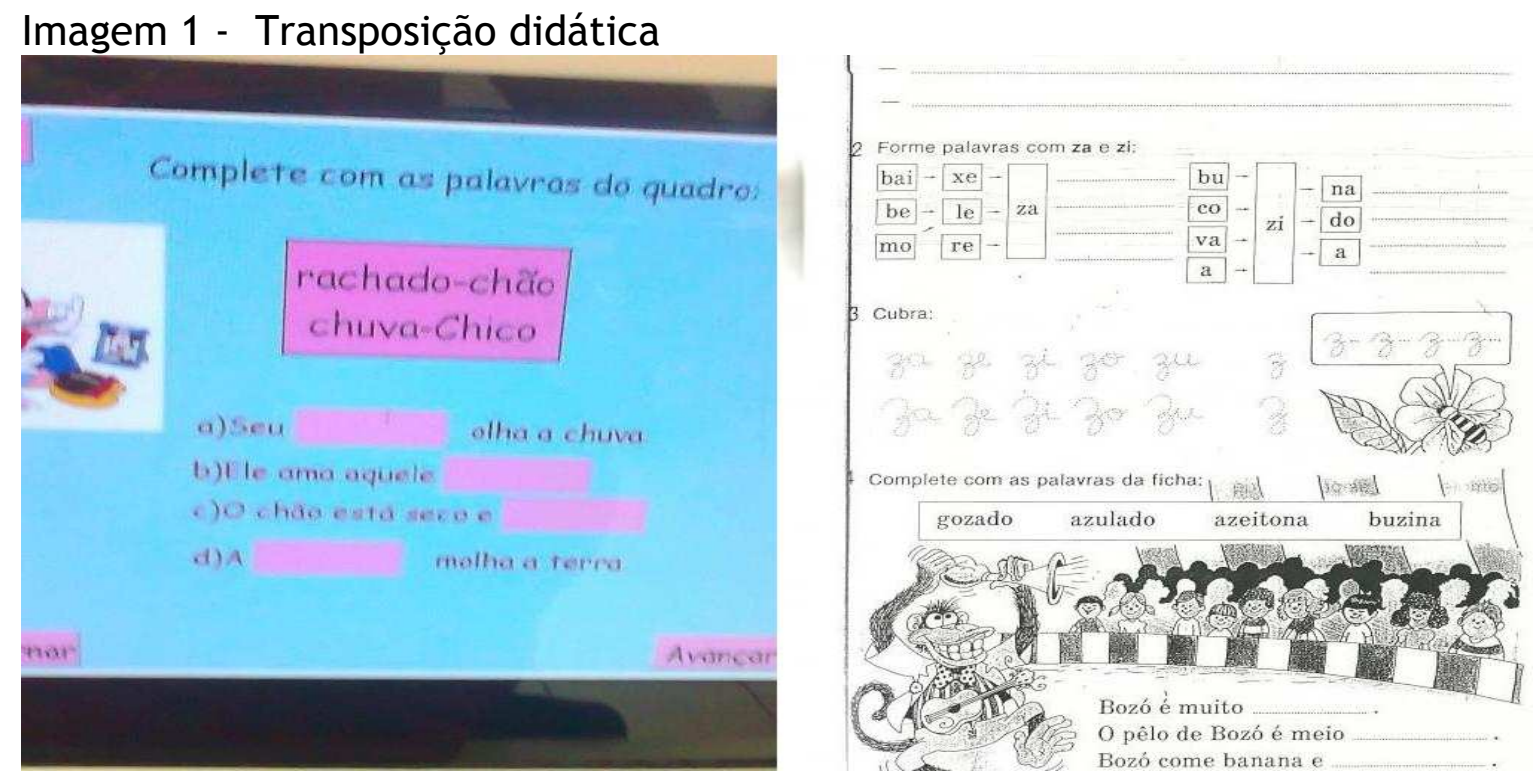

Fonte: Primeira imagem: tela do computador - sala de informática. Segunda imagem: Cartilha Alegria do Saber.

Pode-se perceber, diante dos dados, que a aula oferece muito pouco em relação à complexidade de informações que os alunos poderiam ter acesso ao utilizar a internet. Lévy (1999) enfatiza a importância de utilizar a rede de computadores e o ciberespaço como ambiente que permite a criação de comunidades virtuais e a troca informações. 
Compartilhando as proposições do autor, esta análise corrobora a ideia de que vivemos em uma sociedade permeada de informações, e, mais importante que ficar reforçando a ortografia das famílias silábicas, seria interessante apresentar a esses alunos o instrumento que permite o acesso às novas fontes de conhecimento, para que aprendessem a usar plenamente a tecnologia e filtrar a gama de novidades que aparecem na tela. Para Silva (1998, p. 27-28), "o ensino crítico da leitura deve mostrar que os livros nada mais são do que a expressão de pensamentos sujeitos a erro, passíveis de serem aprofundados e questionados." Para ele, o mundo digital ganhou vida porque se constitui em um espaço dominado pelas imagens e os hipertextos; nele há pluralidade de textos, por isso pode ser um grande aliado no ensino da leitura.

\section{A Biblioteca}

A biblioteca era gerenciada por duas professoras que ocupavam a função de bibliotecárias, uma para cada turno. Durante a entrevista, relataram sobre seu uso, suas funções e expressaram suas opiniões com relação à importância desse espaço para a formação dos leitores. Infelizmente, o papel primordial de ambas as funcionárias era o de realizar a catalogação dos materiais e o empréstimo de livros, que deveria ser feita semanalmente para todas as turmas.

As segundas-feiras eram reservadas para cuidar do espaço interno da biblioteca, por isso nenhum aluno ou professor poderia utilizá-la neste dia, já que ele era dedicado à recuperação de livros danificados, catalogação, coleta de materiais que foram utilizados em sala de aula, levantamento de materiais novos e usados, registro da retirada de jogos e de livros, preenchimento de planilhas para declaração do patrimônio escolar, recebimento dos livros distribuídos por editoras e organização de uma pequena mostra pedagógica de materiais que a escola possuía. Entretanto, um único dia na semana não era suficiente para a realização de todas as atividades previstas.

Os professores, juntamente com seus alunos, podiam usar a biblioteca escolar uma vez por semana para desenvolver diferentes atividades, no entanto esse tempo era destinado exclusivamente para empréstimos de livros. 
Cada aluno tinha em média três minutos para escolha. Caso ultrapassasse esse tempo, a funcionária insistia para que retirassem o livro, pois deveriam retornar à fila e à classe. Essa organização possibilitava que o tempo fosse hábil para atender a todos os outros que ainda estavam em sala. Durante as entrevistas, os alunos reclamavam sobre este problema. 0 aluno 0 . disse que, às vezes, escolhia sem aos menos olhar para o livro, porque era necessário voltar para a fila, pois, caso demorasse um pouco, a professora perguntava se ele tinha passeado pela escola. Se, porventura, o aluno se esquecesse de trazer o livro emprestado na semana anterior, ficava proibido de retirar qualquer material até a regularização da situação. Sobre o momento da devolução dos livros, a professora que atuava na biblioteca disse: “Eu sondo alguns aqui durante o empréstimo; é rapidinho, o professor fala: "vai rápido, pega o livro lá, não fica fazendo hora”. Eu me sinto até pressionada, eu falo: e aí, gostou? Fala de quê? Esse trata de qual assunto? Sugiro que alguém escreva para mim sobre o livro" (Entrevista 28 mar. 2013).

A situação dos empréstimos era determinada pelo tempo dedicado a essa atividade. Uma alternativa para resolução desse problema seria a contratação de um bibliotecário, porque saberia gerenciar a parte de catalogação e demais serviços referentes ao espaço da biblioteca escolar, assim a pedagoga poderia contribuir com o apoio pedagógico para algumas atividades. Essa situação seria ideal, mas ainda não pode ser alcançada devido a diversos fatores, entre os quais as políticas públicas, que não valorizam o bibliotecário escolar. Os livros ficavam em separadores. Essa forma de exposição dificultava a escolha da obra, porque não possibilitava o manuseio completo de todo o livro. Desse modo, restaria apenas a capa para auxiliar na escolha.

A professora que ocupa o lugar de bibliotecária poderia disponibilizar as obras sobre as mesas, mas, na maior parte do tempo, durante a observação, estas estavam ocupadas por materiais didáticos ou enfeites e adereços de festa junina. Os alunos continuavam a olhar os livros nas condições apresentadas, sem que pudessem manuseá-los. Os que ficavam escondidos atrás dos primeiros não eram vistos, porque a fila era organizada para que os alunos passassem em frente ao separador, sem interromper o passo. 
O espaço da biblioteca era muito pequeno para contação de histórias. Em média quinze alunos enfileirados ocupavam o local e não havia espaço para circular no ambiente. Ao fundo, na parte superior, havia uma estante com livros didáticos, impedidos de serem emprestados. Por vezes, pode-se pensar que a biblioteca constitui-se em um espaço para depósitos de materiais inúteis que ainda acabam por atrapalhar as práticas docentes em suas atividades. Conforme Silva (1998, p. 20-21),

Como a grande maioria das escolas não possui infra-estrutura adequada (funcionários, sala para biblioteca, bibliotecário) [...] e muito menos o tempo necessário para discutir a sua dinamização por professores e alunos, então a leitura fica sendo tratada como paliativos em regime de urgência, o que não modifica muitos as coisas.

$\mathrm{Na}$ realidade investigada, o espaço da biblioteca era o equivalente ao que se denomina por almoxarifado, já que ela armazenava materiais de festas e de uso pedagógico. Diante de tal organização e tal espaço físico, esse ambiente só oferecia às crianças o empréstimo de livros, limitado a um horário determinado por semana para cada classe.

Ao longo da história, o acesso à leitura e o comportamento dos leitores se modificaram devido às mudanças dos suportes, desde a pedra até as telas atuais. Para uma biblioteca existir não é preciso ocupar um espaço físico enorme, mas poderia ser considerada uma ideia radical uma escola oferecer somente materiais on-line em seu acervo. Hoje a capacidade de armazenamento de informações é quase ilimitada e, por isso, uma pessoa pode ter sua própria biblioteca sem necessitar de um amplo espaço físico. Existem aplicativos ou programas como o Calibre ou Koobits que são capazes de organizar e separar os arquivos digitais. É possível criar uma estante de livros virtuais que ocuparia apenas as "estantes” de um computador.

A maior biblioteca on-line do mundo é gerenciada pela Organização das Nações Unidas para Educação, Ciências e Cultura (UNESCO) denominada World Digital Library, e conta com a separação de milhares de obras por continente. A biblioteca não deveria ser organizada da mesma maneira que em séculos anteriores, quando disponibilizava aos usuários basicamente livros ou enciclopédias, mas se espera que ela armazene diversificados tipos de 
recursos, desde os materiais impressos até os de multimídia. Para que isso ocorra, sua organização deve levar em conta o espaço para obras impressas e o espaço e tecnologia para o acesso aos arquivos eletrônicos; acima de tudo, quem a planeja não pode se esquecer de que ela é também um lugar de encontro e de diálogos.

0 fato é que os modos de ler foram construídos pelos homens nas relações sociais, culturais e históricas. A criação de novos materiais, de novos suportes de leitura, criou também novos comportamentos leitores. É cultural o hábito de realizamos uma leitura silenciosa quando estamos em uma biblioteca. Essa prática, como tantas outras, acompanha o ato de ler por gerações. Era comum, no processo da pesquisa exposta neste artigo, observarse a professora regente pedir para que os alunos lessem com os olhos. A leitura silenciosa ultrapassou séculos, e orientações docentes como essa possivelmente atravessaram também várias épocas (CHARTIER, 1999).

Esse tipo de leitura é o mais recorrente em nossa sociedade, principalmente em espaços públicos. São casos em que o comportamento dos leitores se altera conforme o ambiente em que a leitura se manifesta. Para Chartier (1999, p. 143), a leitura "[...] é realizada em um espaço coletivo, mas ao mesmo tempo ela é privada, como se o leitor traçasse, em torno de sua relação com o livro, um círculo invisível que o isola". São práticas que acompanham a evolução da humanidade, ainda usadas na prática pedagógica.

\section{O Quiosque}

A professora de literatura utilizava algumas vezes um pequeno lugar chamado quiosque, isto é, uma construção retangular, sem paredes, de poucos metros quadrados, construída em uma área destinada às brincadeiras das crianças. Ao usar esse local, a professora tentava diversificar os ambientes de aprendizagem e dizia:

Eu uso a sala de informática, clipe de música ou filme, às vezes para digitar algum livrinho. Uma coisa que adoro é escrever a opinião dos alunos sobre as atividades, sempre peço para eles escreverem o que eles acharam do material que usei; eu gostei do texto aquarela porque ela fala da riqueza da imaginação. E eu reforço a opinião deles, se gostam ou não do que faço. Se tivesse uma sala de vídeo eu 
usaria, a biblioteca dá para usar quando não esta ocupada. Aqui nesta escola eu não saio muito para fora da sala, na outra escola tinha o dia do tapete, que era o dia em que a turma sai para ler. Aqui eu não saio muito, os lugares são pequenos, a escola é pequena, às vezes atrapalha, às vezes levo eles para o quiosque (Professora M. - Entrevista 9 abr. 2013).

Embora fosse esporádica, a utilização do quiosque para leitura era importante, porque as crianças gostavam desse espaço, uma área pequena coberta com o telhado de um antigo parquinho. Geralmente, o local era utilizado por professores, em diferentes tipos de atividades, e, no momento do recreio, por alunos. No cotidiano da prática pedagógica, ele era usado para jogos, leitura, dia do brinquedo e comemorações festivas. Configurava-se em um espaço que proporcionava uma mudança em relação à dinâmica cotidiana de sala de aula, além de ser um local extramente agradável, aconchegante e bem ventilado se comparado à sala.

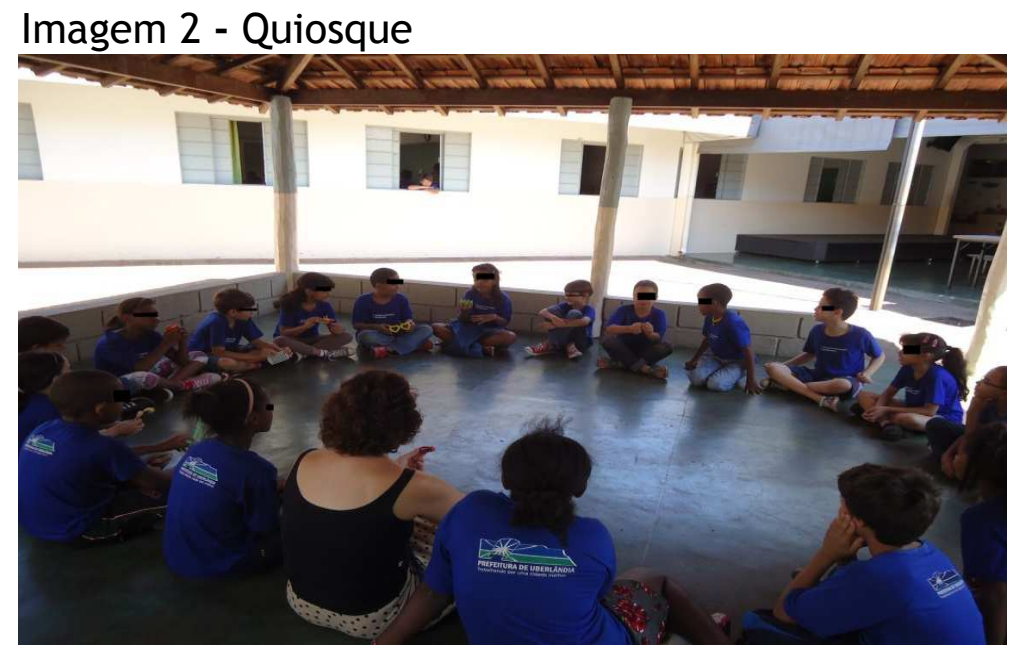

Fonte: A autora.

A imagem 2 reproduz uma aula no quiosque, cuja proposta era a de construção oral compartilhada de uma história. A professora iniciava contando uma história inventada, e, assim, cada aluno, por sua vez, deveria prosseguir, contudo tinha que inserir na história o objeto que a professora the entregava. O próximo aluno tentava englobar seu objeto e assim sucessivamente até o final da elaboração do grupo. O espaço, a dinâmica e as adaptações proporcionaram a participação dos alunos. Durante a observação, em nenhum momento houve interrupções para manter a disciplina, como acontecia 
frequentemente em sala. Todos estavam efetivamente envolvidos nas atividades. Entretanto, a atividade que ali se desenvolveu não foi de leitura propriamente dita. Há diferenças entre o ato de contar histórias, o de criar histórias e o de ler um livro de história.

No mesmo ambiente, em outro momento, foi possível acompanhar a professora regente na condução de uma atividade específica de leitura, que era desenvolvida toda sexta-feira. A professora conduzia a turma para esse espaço, fazia uma roda com os alunos e distribuía um exemplar de um determinado livro - geralmente, textos curtos que continham uma moral para cada um deles; a todos era solicitada a transmissão vocal de um parágrafo.

Ao término da atividade, a professora perguntava se os alunos tinham gostado de ler e fazia oralmente as perguntas de interpretação. Ao retornar à sala, ela colocava perguntas na lousa: nome do livro, dos autores, das personagens, assunto abordado e terminava sempre pedindo um desenho do episódio que mais agradara aos alunos. Isso tudo era feito para ser registrado no caderno. Para Silva (1998, p. 7), com essas práticas,

Privilegia-se o consumo rápido de textos; não sobra tempo para a discussão das ideias, para a exposição das interpretações individuais e para a partilha das experiências geradas pela incursão de texto. Por outro lado [...] professores ainda tomam o ato pedagógico como sinônimo de leituras efetuadas, o que é restringir ou distorcer completamente a dimensão da abrangência desse ato.

O autor não condena a prática pedagógica da leitura relacionada à tarefa de reconhecer assuntos abordados no texto. Entretanto, sugere que as atividades envolvam mais diálogos, criem possibilidades de as crianças, ao realizar a leitura, fazerem conexão com outras experiências.

\section{Últimas Palavras}

Ao longo deste texto foi apresentada uma situação particular de uso do espaço escolar para a promoção da leitura com crianças de $2^{\circ}$ ano do ensino fundamental. Em nenhum momento, a intenção foi indicar qual a melhor forma de utilizar os espaços de uma escola de modo a favorecer o ensino da 
leitura, nem apontar se a abordagem do professor estava adequada ou não a alguma vertente teórica que estuda leitura, nem mesmo apresentar determinados julgamentos sobre as concepções que os professores possuíam sobre aprendizagem ou ensino da leitura.

Uma teoria da leitura, por mais elaborada que seja, não consegue abarcar as múltiplas variáveis que envolvem a educação; não existe uma atividade de ensino de leitura que se aplique a todos os alunos, pois muitas e diferentes práticas são geradas a partir do propósito que se tem ao ensinar. Cada tipo de texto exige do leitor uma conduta; ninguém lê um texto jornalístico da mesma forma que lê um texto narrativo ficcional ou um gibi. Diferentes atos de leitura são exigidos pelas diversas situações sociais: proferir um texto, dar voz a ele em uma conferência é muito diferente da leitura silenciosa de um texto; cada ação exige uma atitude diferente que envolve um ato cultural diferente.

O espaço físico também traz implicações nesse processo. Um ambiente bem organizado, com materiais e móveis adequados, auxilia o ensino. Sabe-se que o calor e abafamento das salas causam mal à saúde dos alunos; é sabido que ter livros na sala de aula não é indicativo da formação de leitores; que longas cópias e a constante busca pelo capricho dos cadernos não possibilitarão formar autores autônomos. Todos esses aspectos têm menor importância quando comparados à mediação que o professor pode realizar nesses espaços por meio de suas práticas.

Segundo Silva (1998), a leitura é o ato que cria possibilidades para o homem viver em sociedade, pois permite a ele compreender seu passado e seu presente na transformação sociocultural do futuro. Por meio da leitura, o indivíduo alcança o conhecimento e pode atingir transformações significativas, porque este ato amplia nossa consciência e nos permite questionar opiniões. 0 desafio de formar leitores não exige apenas que os livros estejam nas mãos dos alunos, uma vez que o ato de ler requer muito mais. Para Kleiman (1989, p. 13),

O processo de ler é complexo. Como em outras tarefas cognitivas, como resolver problemas, trazer a mente uma informação necessária, aplicar algum conhecimento a uma situação nova, o engajamento de muitos fatores (percepção, atenção, memória) é essencial se querermos fazer sentido do texto. 
A seguir, no quadro 1, pode-se comparar e perceber as diferentes concepções de leitura dos profissionais da educação envolvidos nesta pesquisa. A professora regente, as professoras de Literatura e Música, os laboratoristas e a professora que atua na biblioteca demonstraram em suas falas, assim como Kleiman (1989), que o processo de ler é complexo, até mesmo quando a tarefa é a de definir o termo leitura.

Quadro 1 - 0 conceito de leitura

\begin{tabular}{|c|c|}
\hline Entrevistados & CONCEITO DE LEITURA \\
\hline $\begin{array}{l}\text { Professoras } \\
\text { de Literatura } \\
\text { e Música }\end{array}$ & $\begin{array}{l}\text { Leitura pra mim é um livro muito bom, com imagens. Leitura é assim: } \\
\text { quando você pega um livro que é muito bom, você não quer parar de ler, } \\
\text { você quer continuar. Eu acredito que leitura seja muito importante; se você } \\
\text { não ler, você não pega o ônibus (G.). } \\
\text { É vida, o conhecimento da humanidade está no livro, é através da leitura } \\
\text { que o aluno vai melhorar a fala, a escrita, o conhecimento. Eu falo pra eles } \\
\text { que se você ver alguém que gosta de leitura, vai ver que a forma de } \\
\text { expressar é diferente, vai procurar falar corretamente [...] (N.). }\end{array}$ \\
\hline $\begin{array}{l}\text { Professora } \\
\text { que atua na } \\
\text { Biblioteca }\end{array}$ & $\begin{array}{l}\text { Pra mim a leitura é um momento de levar à imaginação, à fantasia, } \\
\text { reconhecer as palavras, preparar um momento (R.). } \\
\text { Pra mim é tudo na vida. Se você não for um bom leitor, falamos pouco, } \\
\text { entendemos pouco (N.). }\end{array}$ \\
\hline Labor & $\begin{array}{l}\text { Tem vários tipos de leitura. } \hat{E} \text { interpretar um conjunto de símbolos, } \\
\text { reconhecer os conjunto de símbolos e depois saber o que quer dizer; por } \\
\text { exemplo, eu reconheço as palavras que são os símbolos, eu monto uma } \\
\text { ideia na cabeça, aí eu vou interpretando aquilo. Na música, eu tenho } \\
\text { símbolos, eu vou saber a nota, a intensidade, o ritmo, e leio e tenho a ideia } \\
\text { que eu preciso dar. A gente lê outras coisas, eu leio a tela, não só palavras } \\
\text { (W.). } \\
\text { Bom, eu acho que é uma forma de conhecimento, ela não está presa só ao } \\
\text { texto escrito, mas há a leitura de imagem, leitura de mundo. A leitura é } \\
\text { uma forma de conhecimento através da qual o aluno pode interagir, vai } \\
\text { começar a se socializar, a se sentir como pessoa. Você não sobrevive sem }\end{array}$ \\
\hline $\begin{array}{l}\text { Professora } \\
\text { Regente }\end{array}$ & $\begin{array}{l}\text { Ler não é só decodificar o texto, você saber ler e interpretar; é um } \\
\text { letramento, é interpretação, às vezes você pode saber ler, mas você é um } \\
\text { analfabeto funcional, igual aos meninos da sala do quinto ano. Tem alguns } \\
\text { que leem bem, às vezes eles estão lendo o texto, mas não entendem o que o } \\
\text { texto quer falar. Falta trabalhar interpretação com eles, eu tento trabalhar, } \\
\text { mas a gente não faz milagre dentro de um ano (M.). }\end{array}$ \\
\hline
\end{tabular}

Fonte: A autora.

O ato de ler não é algo fácil e simples de ser ensinado, já que exige dos indivíduos determinado preparo e, acima de tudo, o reconhecimento de sua importância social. É possível perceber na fala dos profissionais que todos têm consciência disso, entretanto há dificuldades em conceituar o termo leitura, e isso pode ser o problema do ensino deste ato social no interior da escola. As respostas são amplas e, por vezes, limitantes. 
A tentativa de conceituação da professora de literatura N. e da bibliotecária N. é ampla demais a ponto de colocar o termo leitura como sinônimo de vida. Falar bem, ter entendimento sobre as coisas, saber escrever, seriam ações que dependeriam exclusivamente da leitura, desta forma vinculam o ensino da leitura ao ensino da escrita. Os pressupostos desta pesquisa não negam as relações que podem se estabelecer entre os termos leitura e escrita, mas os consideram processos de natureza distinta. Os procedimentos metodológicos e as práticas pedagógicas devem ser planejados e especificamente organizados para o ensino da leitura e da escrita.

A laboratorista P. complementa essa mesma ideia ao dizer que não existe só a leitura do texto, mas a leitura de mundo. Ela entende que é difícil conceituar um ato complexo que exige uma resposta complexa ao dizer: "não sei explicar direito com os termos certos".

Já em outra perspectiva, o laboratorista W. disse que ler é interpretar, reconhecer signos e símbolos. Está presente em sua fala uma importante relação entre a palavra, o signo e sua relação com o significado. Decodificação de letras é uma das habilidades necessárias à leitura, mas não a mais importante.

Ler não é somente localizar as informações, mas por meio deste ato se criam possibilidades para que os leitores realizem conexões com o mundo, permitindo, assim, fazer inferências sobre diversos assuntos. Segundo Foucambert (1994, p. 5), “ler significa ser questionado pelo mundo e por si mesmo, significa que certas respostas podem ser encontradas na escrita, significa poder ter acesso a essa escrita, significa construir uma resposta que integra parte de novas informações ao que já se é”.

A escrita e a leitura são entendidas por W. como um processo que não se esgota na informação impressa. Atribuir sentido a um texto demanda, além de estratégias de leitura, tempo e conhecimento sobre o assunto. A fragilidade de sua conceituação se encontra no fato de entender que não apenas palavras podem ser lidas, mas também os sons da música. Utilizar o termo leitura para qualquer outro ato que não seja o ato de atribuir sentido a um texto gráfico pode trazer problemas para elaborar uma metodologia de ensino. Ensinar a ler uma partitura e compreender as frases musicais é diferente de ensinar a uma 
criança a tecnologia da escrita. Cada ato tem sua particularidade e, portanto, requer ações distintas no percurso metodológico do professor.

A bibliotecária $R$. não conceitua leitura, mas ressalta os efeitos cognitivos que o texto literário pode proporcionar ao leitor: a imaginação, a fantasia, porque trabalha em uma biblioteca escolar, que hoje no Brasil tem recebido obras literárias por meio das políticas públicas de distribuição de livros. A biblioteca é um lugar de pesquisa e, por isso, precisa ter um acervo diversificado, impresso ou virtual.

A professora $G$. entende a leitura como sinônimo de compreensão do mundo. Sua fala indica que não basta o aluno oralizar um texto, porque este ato não poderia receber o mesmo nome que outro que envolve compreensão. Ao contrário, a professora G. associa a leitura apenas às questões funcionais: se você não souber, não pode pegar o ônibus. É possível tomar um ônibus sem que se saiba ler, evidentemente com dificuldades; mas é impossível se apropriar do conhecimento acumulado sem saber ler. Não ser leitor é uma forma de exclusão social.

Além de a leitura estar associada às tarefas escolares, ela tem um objetivo maior: o de desenvolver as capacidades humanas ainda não desenvolvidas. É importante que o aluno entenda o que está lendo e faça relação com outras vivências, algumas simples como ler as instruções sobre uma boa conduta escolar, mas também as não tão pragmáticas, ligadas à produção cultural das Artes, necessárias para sua humanização.

\section{Referências}

ANDRÉ, M. E. D. A. Etnografia da prática escolar. 12. ed. São Paulo: Papirus, 1995.

ARENA, D. B. Atos de leitura: funções e características. In: ENCONTRO DE PESQUISA EM EDUCAÇÃO DA ANPED CENTRO OESTE, 10., 2010, Uberlândia. Anais... Uberlândia: FACED UFU, 2010. v. 1. p. 1-10.

BAJARD, E. Manifesto dos usuários da escrita. Ensino em Re-Vista, Uberlândia, v. 21, n. 1, p. 189-195, jan./jun. 2014.

CEREJA, W. R.; MAGALHÃES, T. C. Gramática reflexiva: texto, semântica e interação. São Paulo: Atual, 2005. 
CHARTIER, R. Aventura do livro do leitor ao navegador. São Paulo: Unesp, 1999.

DWYER, T. et al. Desvendando mitos: os computadores e o desempenho escolar no Sistema. Educação e Sociedade, Campinas, v. 28, n. 101, dez. 2007. Disponível em:

<http: / /www.scielo.br/scielo.php?script=sci_arttext\&pid=\$0101733020070004 $00003 \&$ Ing=en\&nrm=iso $>$ Acesso em: 1 jul. 2013.

FOUCAMBERT, J. A leitura em questão. Tradução de Bruno Charles Magno. Porto Alegre: Artes Médicas, 1994.

KLEIMAN, A. Leitura: ensino e pesquisa. Campinas: Pontes, 1989.

KRAMER, S. Leitura e escrita de professores em suas histórias de vida e formação. Cadernos de Pesquisa, São Paulo, n. 106, p. 129-157, mar. 1999.

LEONTIEV, A. N. Sobre o desenvolvimento histórico da consciência. In: 1978. O desenvolvimento do psiquismo. Lisboa: Horizonte Universitário,

LÉVY, P. Cibercultura. São Paulo: Editora 34, 1999.

SILVA, E. T. Elementos da pedagogia da leitura. 3. ed. São Paulo: Martins Fontes, 1998.

SMITH, F. Compreendendo a leitura: uma análise psicolinguística da leitura e do aprender a ler. Tradução de Daíse Batista. 4. ed. Porto Alegre: Artes Médicas, 1989.

VIGOTSKY. L. S. Imaginação e criação na infância: ensaio psicológico- livro para professores. Tradução de Zoia Prestes. São Paulo: Ática, 2009. 